\title{
PERANCANGAN DAN PENJADWALAN AKTIVITAS DISTRIBUSI HOUSEHOLD PRODUCT MENGGUNAKAN METODE DISTRIBUSI REQUIREMENT PLANNING (DRP) DI PT XYZ UNTUK MENYELARASKAN PENGIRIMAN PRODUK KE RITEL
}

\section{HOUSEHOLD PRODUCT DISTRIBUTION ACTIVITY PLANNING AND SCHEDULING USING DISTRIBUTION REQUIREMENT PLANNING (DRP) IN PT XYZ TO SYNCRONIZE OF PRODUCT SHIPPING TO RETAIL}

\author{
${ }^{1}$ Muhammad Bolkiah Muttaqin, ${ }^{2}$ Sri Martini, ${ }^{3}$ Rio Aurachman \\ 1,2,3 Program Studi Teknik Industri, Fakultas Rekayasa Industri, Telkom University \\ 1bolkiah22@gmail.com, ${ }^{2}$ srimartini59m@gmail.com, ${ }^{3}$ rio_aurachman@yahoo.com
}

\begin{abstract}
Abstrak- PT XYZ merupakan perusahaan yang menjual produk rumah tangga yang memiliki tiga Distribution Centre (DC). DC mengirimkan produknya ke lima ritel yaitu ritel 1 , ritel 2 , ritel 3 , ritel 4 dan ritel 5. PT XYZ dalam proses pendistribusiannya belum melakukan suatu perencanaan dan penjadwalan aktivitas distribusi produk, sehingga mengakibatkan terjadinya penumpukan dan kekurangan persediaan produk pada ritel. Berdasarkan permasalahan tersebut, maka dilakukan perancangan penjadwalan aktivitas distribusi dengan menggunakan metode Distribution Requirement Planning $(D R P)$. DRP mengantisipasi kebutuhan mendatang dengan perencanaan pada setiap level dalam jaringan distribusi. Dengan metode DRP, dilakukan perencanaan distribusi terhadap permintaan produk oleh ritel kepada DC dengan menggunakan tabulasi DRP yang mempertimbangkan safety stock dan kapasitas armada pengiriman sehingga diperoleh penghematan biaya distribusi dan pengiriman produk yang optimal. Hasil yang didapatkan dari penelitian ini adalah berkurangnya pengiriman produk yang melebihi atau kurang dari kebutuhan ritel yang dapat mengakibatkan penumpukan dan kekurangan persediaan produk. Dengan menggunakan metode DRP dapat diperoleh penghematan biaya pengiriman sebesar $21 \%$ atau sebesar Rp 50.475.991 selama periode Januari 2016-Desember 2016. Diharapkan dengan adanya perencanaan dan penjadwalan aktivitas distribusi ini, pemenuhan permintaan pelanggan akan menjadi optimal, kinerja penjualan meningkat dalam memenuhi order dengan tepat waktu dan tepat jumlah.
\end{abstract}

Kata kunci: Distribusi, Penjadwalan, Distrbution Requitement Planning $(D R P)$, safety stock

Abstract- - PT. XYZ is household product selling company that has three Distribution Centre (DC). It sends products to 5 ritels which are ritel 1, ritel 2, ritel 3, ritel 4 and ritel 5. The company is still not doing planning and scheduling which caused pile and lack of products in ritel. Based on the problem, Distribution Requirement Planning (DRP) method is used to plan distribution scheduling. DRP anticipates future needs with planning on every level of distribution network. DRP Method does distribution planning towards product demand from ritel to DC which considers safety stock and shipping fleet capacity so distribution cost is reduced and product delivery will be optimum. The result obtained from this study are reduced delivery products that exceed or less than what the ritel needs which leads to both pile and lack of products availability. Then the efficiency of shipping cost obtained, where the difference between actual shipping cost and proposed shipping cost is Rp 50.475.991,- or $21 \%$ savings for 12 months. With the wellcoordinated planning and distribution scheduling activites, it is expected to have the consumers demand fulfilled, sales performance increases in fulfilling orders at the exact amount and time.

Keywords: Distribution, Schedulinng, Distrbution Requitement Planning (DRP), safety stock

\section{PENDAHULUAN}

Pendistribusian barang merupakan salah satu bagian penting dari sistem logistik. Dalam dunia logistik, distribusi (Moving goods from the origin to destination) merupakan suatu kegiatan strategis dalam proses memindahkan barang dari tempat dimana barang tersebut diproduksi hingga sampai dimana barang tersebut akan dipakai. Pada dasarnya kegiatan distribusi tidak hanya berfokus pada aktivitas fisik seperti pengiriman saja, namun juga memikirkan tentang bagaimana melakukan perancangan jaringan distribusi, segmentasi/ clusterisasi titik distribusi, penjadwalan, penentuan rute dan menentukan konsolidasi pengiriman [1].

PT XYZ merupakan salah satu perusahaan yang menjual produk rumah tangga dan memiliki Distribution Center (DC). DC yang mengelola pengiriman produk sejumlah 63 unit untuk pengiriman ke lima ritel. Dalam pendistribusian yang dilakukan oleh PT XYZ dari DC menuju ritel didasarkan atas sales order dari setiap ritel sesuai dengan perhitungan replenishment, dimana stok produk yang keluar atau terjual oleh ritel, akan diisi kembali sesuai dengan safety stock. 
PT XYZ dalam mendistribusikan produknya menggunakan armada perusahaan yaitu Colt Diesel Engkel (CDE), Grandmax dan Truck Engkel Box dengan kapasitas perkendaraan dapat dilihat pada Tabel 1.

Tabel 1 Data Kapasitas Armada Masing-Masing Ritel
\begin{tabular}{|c|c|c|c|}
\hline No & Ritel & Jenis Armada & Kubikasi m3 \\
\hline 1 & Ritel 1 & CDE & 11.25 \\
\hline 2 & Ritel 2 & GranMax & 4.68 \\
\hline 3 & Ritel 3 & Truck Engkel Box & 7.94 \\
\hline 4 & Ritel 4 & Truck Engkel Box & 7.94 \\
\hline 5 & Ritel 5 & Truck Engkel Box & 7.94 \\
\hline
\end{tabular}

Pada Tabel 1 dapat diketahui bahwa setiap ritel memiliki jenis dan kapasitas armada yang berbeda. Dimana pengiriman produk kebutuhan ritel/minggu tidak dapat dikirim melebihi dari kapasitas masing-masing armada. Perusahaan menggunakan sistem distribusi dorong. Dimana, pengiriman dari pusat induk distribusi ke pusat distribusi regional atau lokal dihitung dan ditentukan oleh pusat induk distribusi. Perhitungan ini didasarkan atas data yang ada di setiap pusat regional dan lokal, yang setiap waktu dimonitor oleh pusat induk [2]. Tabel 2 merupakan data kebutuhan produk / minggu di masing-masing ritel.

Tabel 2 Data Kebutuhan produk (minggu)

\begin{tabular}{|c|c|c|}
\hline Ritel & Kebutuhan (Karton) & Kubikasi (m3) \\
\hline Ritel 1 & 151 & 7.31 \\
\hline Ritel 2 & 98 & 5.87 \\
\hline Ritel 3 & 127 & 5.59 \\
\hline Ritel 4 & 89 & 4.04 \\
\hline Ritel 5 & 118 & 5.11 \\
\hline
\end{tabular}

periode berikutnya akan terjadi penumpukan produk. Dan terdapat kebutuhan produk yang utilitasnya kurang dari kapasitas aramada sehingga terjadi penundaan pengiriman dan usaha untuk pemenuhan full truck load. Penundaan pengiriman, hutang kirim dan full truck load menyebabkan tidak sesuainya pengiriman yang dilakukan oleh DC dengan kebutuhan ritel.

Melihat dari permasalahan yang dialami oleh PT XYZ, maka diperlukan suatu perencanaan dan penjadwalan aktivitas distribusi produk untuk memenuhi permintaan agar perusahaan dapat mencapai target optimal pengiriman dengan menggunakan metode Distribution Requirement Planning (DRP). Distribution Requirement Planning merupakan metode dari Material Requirement Planning (MRP) yaitu untuk mendistribusikan persediaan yang bertujuan untuk merencanakan kebutuhan produk jadi melalui jaringan distribusi. Bill Of Material yang digunakan dalam MRP diganti menjadi Bill Of Distribution untuk menentukan jaringan distribusinya [3]. Distribution Requirement Planning (DRP) dapat mengatur ketersediaan produk dan menentukan perencanaan serta penjadwalan distribusi dan dapat meningkatkan kinerja penjualan perusahaan dalam memenuhi permintaan konsumen dengan waktu yang tepat, jumlah yang tepat, dan lainnya [4].

\section{HASILDAN PEMBAHASAN}

Alur pemecahan penelitian ini digambarkan melalui model konseptual penelitian yang tercantum pada Gambar 1.

Terdapat kebutuhan produk di ritel 2 melebihi kapasistas armada yang tersedia sehingga terjadi hutang kirim dan pada

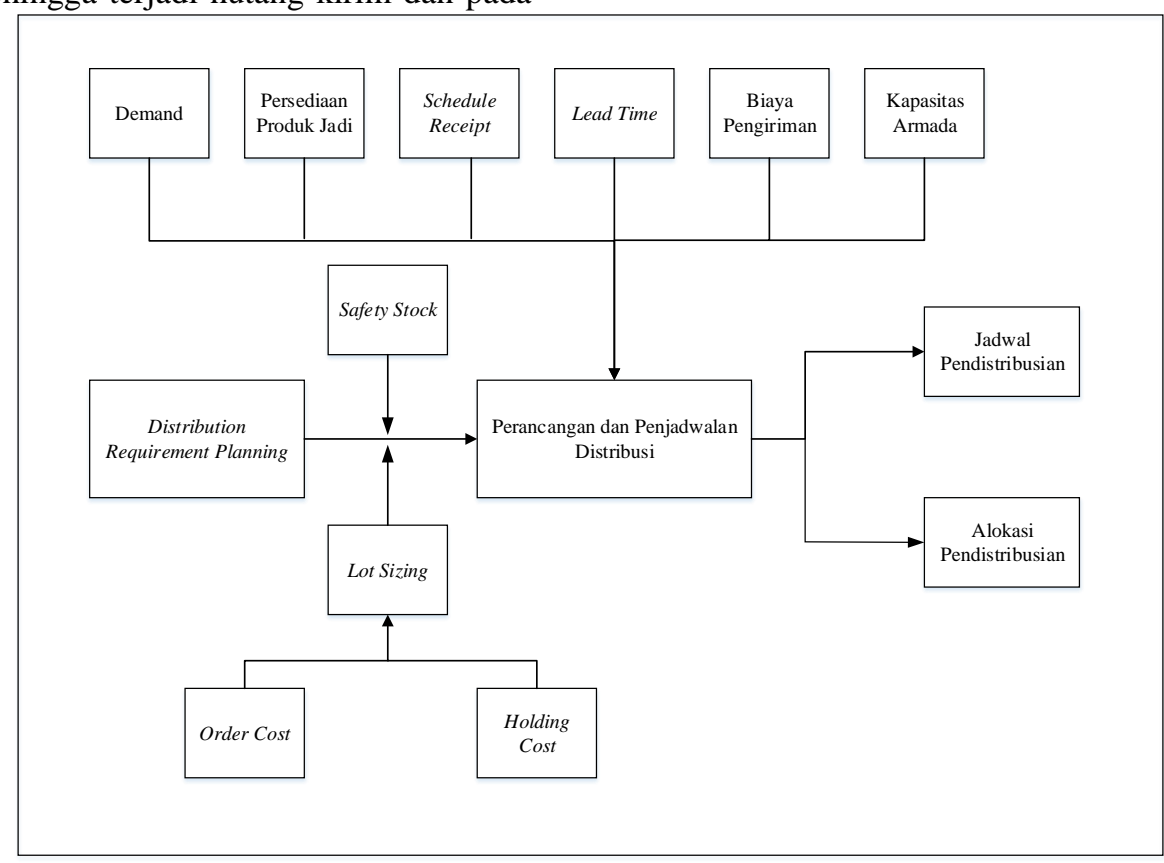

Gambar 1 Model Konseptual Penelitian 
Gambar 1 di dalam penelitian ini menggunakan metode Distribution Requirement Planning (DRP) untuk perencanaan penjadwalan aktivitas distribusi. Diawali dengan ketersediaan data yaitu data demand (sales order) atau permintaan produk oleh setiap ritel kepada DC, data persediaan produk jadi di setiap ritel, data Schedule Receipt atau kedatangan produk yang sudah dijadwalkan sebelumnya, informasi lead time pengiriman produk dari DC menuju ritel, biaya pengiriman dan informasi kapasitas armada pengiriman.

Data permintaan produk yang digunakan pada penelitian ini merupakan data permintaan pada tahun 2016 dari DC ke 5 ritel yang berada di Jawa Barat. Terdapat 63 jenis produk yang di distribusikan oleh DC menuju ke 5 ritel. Permintaan produk oleh ritel kepada DC berbeda-beda jumlah dan jenis produk setiap bulannya. Pada pembahasan ini akan difokuskan kepada jenis produk yaitu Toples Kecil.

Tabel 3 Data Permintaan Toples Kecil

\begin{tabular}{|l|c|c|c|c|c|}
\hline \multicolumn{1}{|c|}{ Bulan } & Ritel 1 & Ritel 2 & Ritel 3 & Ritel 4 & Ritel 5 \\
\hline Januari & 95 & 80 & 70 & 80 & 60 \\
\hline Februari & 20 & 40 & 30 & 55 & 15 \\
\hline Maret & 95 & 65 & 40 & 80 & 35 \\
\hline April & 90 & 25 & 0 & 30 & 15 \\
\hline Mei & 155 & 80 & 50 & 105 & 55 \\
\hline Juni & 110 & 100 & 90 & 105 & 75 \\
\hline Juli & 155 & 90 & 50 & 105 & 55 \\
\hline Agustus & 30 & 25 & 40 & 40 & 20 \\
\hline September & 120 & 65 & 15 & 55 & 15 \\
\hline Oktober & 95 & 90 & 40 & 80 & 35 \\
\hline November & 95 & 90 & 40 & 80 & 35 \\
\hline Desember & 95 & 70 & 20 & 68 & 20 \\
\hline
\end{tabular}

Data persediaan produk toples kecil untuk masing-masing ritel pada bulan desember 2016 dapat dilihat pada Tabel 4. Sedangkan untuk ukuran produk dapat dilihat pada Tabel 5. Masing-masing ritel memilik lead time 1 hari. Data jenis armada dan ongkos kirim masing-masing ritel dapat dilihat pada Tabel 6 dan ongkos simpan pada Tabel 7 .

Tabel 4 Data Persediaan Toples Kecil

\begin{tabular}{|c|c|c|c|c|c|c|}
\hline No & Produk & Ritel 1 & Ritel 2 & Ritel 3 & Ritel 4 & Ritel 5 \\
\hline 1 & Toples kecil & 5 & 7 & 7 & 7 & 7 \\
\hline
\end{tabular}

Tabel 5 Data Ukuran Toples Kecil

\begin{tabular}{|} 
Tabel 5 Data Ukuran Toples Kecil \\
\begin{tabular}{|c|c|c|c|c|c|}
\hline \multirow{2}{*}{ No } & \multirow{2}{*}{ Produk } & \multicolumn{3}{|c|}{ Ukuran (cm) } & \multirow{2}{*}{ Kubikasi (m3) } \\
\cline { 3 - 5 } & & Panjang & Lebar & Tinggi & \\
\hline 1 & Toples kecil & 25 & 18 & 11 & 0,005 \\
\hline
\end{tabular}
\end{tabular}

Tabel 6 Data Ongkos Kirim

\begin{tabular}{|c|c|c|c|}
\hline Ritel & Jenis Armada & Kapasitas $\mathrm{m}^{3}$ & $\begin{array}{c}\text { Ongkos } \\
\text { Pengiriman }\end{array}$ \\
\hline Ritel 1 & CDE & 11,25 & Rp277.624 \\
\hline Ritel 2 & GranMax & 4,68 & Rp183.560 \\
\hline Ritel 3 & Truck Engkel Box & 7,94 & Rp196.944 \\
\hline Ritel 4 & Truck Engkel Box & 7,94 & Rp217.544 \\
\hline Ritel 5 & Truck Engkel Box & 7,94 & Rp207.244 \\
\hline
\end{tabular}

Tabel 7 Data Ongkos Simpan

\begin{tabular}{|c|c|c|}
\hline Ritel & Biaya Simpan $/ \mathrm{m}^{3}$ & Daya Tampung Produk \\
\hline Ritel 1 & Rp 926 & 5500 \\
\hline Ritel 2 & Rp 643 & 5000 \\
\hline Ritel 3 & Rp 714 & 4500 \\
\hline Ritel 4 & Rp 838 & 4500 \\
\hline
\end{tabular}

\begin{tabular}{l|l|r} 
Ritel 5 & Rp 686 & 5500 \\
\hline
\end{tabular}

Biaya pengiriman yang dikeluarkan berdasarkan jumlah dan jenis armada yang digunakan untuk melakukan pengiriman produk dari DC menuju masing-masing ritel. Sehinga didapatkan total biaya pengiriman aktual sebesar Rp237.155.132. Dalam membuat penjadwalan distribusi menggunakan metode DRP didahului dengan menentukan order quantity (Lot Size) yang akan digunakan. Pada penelitian ini, ritel yang melakukan permintaan kepada DC adalah customer. Sehingga jumlah pengiriman produk haruslah sesuai dengan kebutuhan atau permintaan ritel. Maka berdasarkan pemaparan masing-masing konsep lot sizing, konsep lot sizing yang tepat digunakan untuk nilai order quantity adalah konsep Lot for Lot. Dibandingkan dengan konsep Fixed Order Quantity (FOQ) dimana jumlah lot adalah tetap, tidak dimungkinkan karena akan dilakukannya konsolidasi pengiriman produk dalam armada pengiriman. Kemudian dibandingkan dengan konsep Fixed Period Requirement (FPR) dimana selang waktu antar pengiriman produk tetap, tidak dimungkinkan karena waktu permintaan produk oleh ritel ke DC tidak tetap.

Setelah didapat metode lot sizing yang digunakan, maka langkah selanjutnya yaitu menentukan Safety stock (SS). Safety stock digunakan untuk pengaman apabila terjadi lonjakan permintaan pada suatu periode, kurangnya jumlah pengiriman atau hal lainnya yang terjadi akibat gangguan dari alam maupun lingkungan perusahaan [5]. untuk menentukan tingkat stock pengaman pada masing-masing produk. Pihak manajemen menentukan tingkat service level yang dipergunakan dalam safety stock adalah sebesar $95 \%$. Sehingga $Z \alpha$ dapat ditentukan dengan melihat Tabel distribusi normal yaitu sebesar 1,64. Formulasi untuk menghitung safety stock adalah [6]:

$\mathrm{S}=\mathrm{B}-\mathrm{D} . \mathrm{L}$

Dimana:

$\mathrm{S}=$ Safety stock

$\mathrm{B}=$ Reorder

$\mathrm{D}=$ Demand

$\mathrm{L}=$ Lead time

Hasil akhir perhitungan safety stock produk Toples Kecil dan Tempat Makan S pada setiap ritel di periode januari dapat dilihat pada Tabel 8.

\begin{tabular}{|c|c|c|c|c|c|}
\hline Trobel 8 Safety stock \\
\begin{tabular}{|c|c|c|c|c|c|}
\hline Produk & Ritel 1 & Ritel 2 & Ritel 3 & Ritel 4 & Ritel 5 \\
\hline
\end{tabular}
\end{tabular}

Nilai Safety stock telah didapat maka selanjutnya adalah menghitung tabulasi DRP. Langkah-langkah menghitung tabulasi DRP adalah sebagai berikut [7]:

1. Tentukan Gross Requirement (kebutuhan kotor) yang diperoleh dari hasil Forecastingt.

2. Hitung Net Requirement (kebutuhan bersih). Berikut rumus dalam periode n: Net Requirement $=($ Gross Requirment + Safety stock $)-($ Schedule Receipt + Project on hand periode sebelumnya).

3. Tentukan Planned Order Receipt sejumlah Net Requirement tersebut (ukuran lot tertentu) pada periode tersebut. 
4. Hitung Projected On hand pada periode $\mathrm{n}$ tersebut: Project On hand $=($ Project On hand Periode sebelumnya + Schedule Receipt + Planned Order Receipt).

5. Tentukan hari dimana harus melakukan pemesanan tersebut (Planned Order Release) dengan mengurangkan hari terjadwalnya Planned Order Receipt dengan Lead time. Untuk mengetahui perhitungan, disajikan tabulasi DRP seperti pada Tabel 9. Setelah dilakukan tabulasi untuk 63 produk maka didapatkan rangkuman Planned Order Release (PORL). Rangkuman PORL untuk 63 produk pada periode Januari dapat dilihat pada Tabel 10.

Tabel 9 Tabulasi Distribution Requirement Planning

\begin{tabular}{|c|c|c|c|c|c|c|c|c|c|c|c|c|c|c|c|c|c|c|c|}
\hline $\mathrm{OH}$ & \multicolumn{10}{|c|}{5} & \multicolumn{9}{|c|}{ Lead Time : 1} \\
\hline \multicolumn{11}{|c|}{ Lot Size : LFL } & \multicolumn{9}{|c|}{ Safety stock: 14} \\
\hline & \multirow{2}{*}{ PD } & \multicolumn{18}{|c|}{ Periode } \\
\hline & & 1 & 2 & 3 & 4 & 5 & 6 & 7 & 8 & 9 & 10 & 11 & 12 & 13 & 14 & 15 & 16 & $\ldots$ & 31 \\
\hline GR & & 0 & 30 & 0 & 0 & 0 & 0 & 0 & 0 & 0 & 25 & 0 & 0 & 0 & 0 & 0 & 0 & $\ldots$ & 0 \\
\hline \multicolumn{20}{|l|}{ SR } \\
\hline $\mathrm{POH}$ & 5 & 14 & 14 & 14 & 14 & 14 & 14 & 14 & 14 & 14 & 14 & 14 & 14 & 14 & 14 & 14 & 14 & $\ldots$ & 14 \\
\hline NR & & 9 & 30 & 0 & 0 & 0 & 0 & 0 & 0 & 0 & 25 & 0 & 0 & 0 & 0 & 0 & 0 & $\ldots$ & 0 \\
\hline PORc & & 9 & 30 & 0 & 0 & 0 & 0 & 0 & 0 & 0 & 25 & 0 & 0 & 0 & 0 & 0 & 0 & $\ldots$ & 0 \\
\hline PORl & 9 & 30 & 0 & 0 & 0 & 0 & 0 & 0 & 0 & 25 & 0 & 0 & 0 & 0 & 0 & 0 & 0 & $\ldots$ & 0 \\
\hline
\end{tabular}

Tabel 10 Rangkuman PORL

\begin{tabular}{|c|c|c|}
\hline Periode & PORl (Karton) & PORl (m3) \\
\hline 1 & 123 & 2.0176 \\
\hline 2 & 151 & 7.3042 \\
\hline 3 & 75 & 3.1643 \\
\hline 4 & 0 & 0 \\
\hline 5 & 48 & 5.2524 \\
\hline 6 & 0 & 0 \\
\hline 7 & 142 & 6.0672 \\
\hline 8 & 0 & 0 \\
\hline 9 & 65 & 0.6782 \\
\hline 10 & 80 & 7.7434 \\
\hline 11 & 0 & 0 \\
\hline 12 & 0 & 0 \\
\hline 13 & 43 & 4.7016 \\
\hline 14 & 166 & 6.2137 \\
\hline 15 & 43 & 4.3421 \\
\hline 16 & 0 & 0 \\
\hline 17 & 0 & 0 \\
\hline 18 & 0 & 0 \\
\hline 19 & 137 & 6.679 \\
\hline 20 & 86 & 9.0728 \\
\hline 21 & 185 & 5.8157 \\
\hline 22 & 0 & 0 \\
\hline 23 & 0 & 0 \\
\hline 24 & 0 & 0 \\
\hline 25 & 148 & 5.3378 \\
\hline 26 & 0 & 0 \\
\hline 27 & 162 & 6.4926 \\
\hline 28 & 0 & 0 \\
\hline 29 & 0 & 0 \\
\hline 30 & 0 & 0 \\
\hline 31 & 0 & 0 \\
\hline
\end{tabular}

Berdasarkan PORl, maka dilakukan konsolidasi atau penggabungan pengiriman produk dalam satu truk, guna melakukan pengiriman produk dengan kondisi truk yang penuh (Full truck load) sehingga dapat menghemat biaya pengiriman. Dalam melakukan konsolidasi pengiriman produk digunakan perhitungan logika Least Total Cost (LTC) dimana mencari ongkos total minimum berdasarkan biaya simpan dan ongkos pengiriman. Pada Tabel 11 merupakan lngkah langkah perhitungan konsolidasi pengiriman produk:

1. Dimulai dengan Planned Order Release (PORl) pada periode awal (past due) yang menjadi rencana pengiriman. Kemudian melihat jenis kapasitas kendaraan yang dapat melakukan pengiriman menuju ritel yang dituju. Untuk ritel 1 , jenis kendaraan yang dapat melakukan pengiriman adalah CDE dengan kapasitas 11,25 m3

2. Dilihat apakah rencana pengiriman sudah mencukupi kapasitas kendaraan sehingga menjadi truk dengan kapasitas penuh (full truck load) atau tidak. Apabila kapasitas truk belum penuh, maka dilakukan perhitungan kurang kapasitas yang didapatkan dari kapasitas kendaraan dikurangi kubikasi rencana pengiriman. Hasil yang dicari adalah kurang kapasitas yang memiliki nilai terkecil karena berarti kondisi full truck load.

3. Menetukan biaya kekurangan jika terjadi kurang kapasitas, yang dihitung berdasarkan prosentase kekurangan kapasitas kendaraan. Biaya kekurangan $=$ (kurang kapasitas (m3) / kapasitas kendaraan (m3)) x biaya pengiriman.

Tabel 11 Least Total Cost

\begin{tabular}{|c|c|c|c|c|c|c|c|c|}
\hline Periode & $\begin{array}{c}\text { POR1 } \\
(\mathrm{m} 3)\end{array}$ & $\begin{array}{c}\text { Akumulasi } \\
(\mathrm{m} 3)\end{array}$ & $\begin{array}{c}\text { Kendaraan } \\
(\mathrm{m} 3)\end{array}$ & $\begin{array}{c}\text { Kurang } \\
\text { kapasitas (m3) }\end{array}$ & $\begin{array}{c}\text { Biaya } \\
\text { Kendaraan }\end{array}$ & $\begin{array}{c}\text { Biaya } \\
\text { Kekurangan }\end{array}$ & $\begin{array}{c}\text { Biaya } \\
\text { Simpan }\end{array}$ & Total Biaya \\
\hline PD & 7,30 & 7,30 & 11,25 & 3,95 & 177624 & 62294 & 0 & 239918 \\
\hline $1^{*}$ & 2,02 & 9,32 & 11,25 & 1,93 & 177624 & 30439 & 1868 & 209931 \\
\hline 2 & 7,30 & 16,63 & 22,50 & 5,87 & 355248 & 92738 & 15397 & 463384 \\
\hline 2 & 5,38 & 5,38 & 11,25 & 5,87 & 177624 & 92738 & 0 & 270362 \\
\hline $3^{*}$ & 3,16 & 8,54 & 11,25 & 2,71 & 177624 & 42778 & 2930 & 223332 \\
\hline 4 & 0,00 & 8,54 & 11,25 & 2,71 & 177624 & 42778 & 2930 & 223332 \\
\hline 5 & 5,25 & 13,79 & 22,50 & 8,71 & 355248 & 137473 & 17523 & 510244 \\
\hline
\end{tabular}


4. Menentukan biaya simpan yang timbul jika dilakukan penggabungan pengiriman dimana rencana pengiriman dikirim lebih awal dari periode sebelumnya. Misal pada periode 1 yang merupakan penggabungan PORl past due dan PORl periode 1 . Biaya simpan = Porl $(\mathrm{m} 3)$ periode past due $\mathrm{x}$ biaya simpan per kubikasi. Biaya simpan per kubikasi untuk ritel 1 yaitu sebesar Rp 926,- yang didapatkan dari perhitungan sebelumnya.

5. Setelah seluruh biaya diketahui, maka dicari total biaya terkecil berdasarkan total biaya periode selanjutnya. Misal pada periode 1 yang merupakan penggabungan pengiriman periode pas due dan periode 1 total biaya yang dikeluarkan yaitu sebesar Rp 209,931 lebih kecil dibandingkan dengan total biaya pada periode selanjutnya yaitu periode 2 sebesar Rp 463,384. Maka periode 1 yang dipilih, dimana berarti rencana pengiriman pada periode past due dan periode 1 dilakukan penggabungan pengiriman.

6. Dari kuantitas penggabungan pengiriman produk yang dipilih pada periode 1 yaitu sebesar $9.32 \mathrm{~m} 3$ dengan kapasitas armada pengiriman $11.25 \mathrm{~m} 3$ maka masih terdapat kekurangan kapasitas sebesar $1.93 \mathrm{~m} 3$. Kekurangan kapasitas ini akan diambil pada PORl periode selanjutnya untuk memenuhi kapasitas armada pengiriman. Dari kekurangan $1.93 \mathrm{~m} 3$ diambil dari PORl periode 2, sehingga PORl pada periode 2 yang sebelumnya $7.30 \mathrm{~m} 3$ dikurangi dengan $1.93 \mathrm{~m} 3$ menjadi $5.38 \mathrm{~m} 3$. Begitu selanjutnya dilakukan untuk periode berikutnya saat terjadi penggabungan pengiriman produk.

\section{ANALISIS}

Perancangan penjadwalan aktivitas distribusi menggunakan metode Distribution Requirement Planning mengidentifikasi kebutuhan ritel dalam setiap harinya kemudian melakukan penjadwalan pengiriman terhadap kebutuhan tersebut dengan mempertimbangkan inventory on hand dan safety stock masing-masing produk pada ritel yang telah dilakukan perhitungan terlebih dahulu. Dengan mempertimbangkan inventory on hand dan safety stock masing-masing produk maka kebutuhan produk oleh Ritel yang masih dapat dicukupi oleh persediaan dan dalam batas aman safety stock tidak dilakukan pengiriman, tetapi kebutuhan produk yang sudah tidak dapat dicukupi oleh persediaan dan melewati batas aman safety stock maka dilakukan pengiriman produk oleh $\mathrm{Hal}$ ini dapat meminimasi pengiriman produk oleh DC menuju masing-masing ritel yang berlebih ataupun kurang dari kebutuhan ritel.

Kemudian dalam perancangan penjadwalan aktivitas distribusi menggunakan metode Distribution Requirement Planning (DRP) dilakukan pula konsolidasi pengiriman produk dalam armada pengiriman, dimana rencana pengiriman yang sudah dibuat yang belum mencukupi kapastitas armada dilakukan penggabungan rencana pengiriman produk dengan lokasi ritel yang sama. Konsolidasi ini dilakukan dengan mempertimbangkan kapasitas armada pengiriman, biaya simpan produk apabila dilakukan penarikan pengiriman, dan biaya keterlambatan apabila produk ditunda pengirimannya dari rencana pengiriman yang sudah dibuat. Dengan dilakukannya konsolidasi pengiriman yang optimal, sehingga tidak terjadi penundaan pengiriman produk karena kurang kapasitas pengiriman (less truck load). Dengan demikian, realisasi kirim produk oleh DC menuju masing-masing ritel dapat seimbang dengan kebutuhan. Setalah dilakukan perhitungan menggunakan metode DRP dilanjutkan dengan konsolidasi maka didapatkan biaya usulan lebih kecil disbanding biaya aktual dapat dilihat pada Gambar 2 .

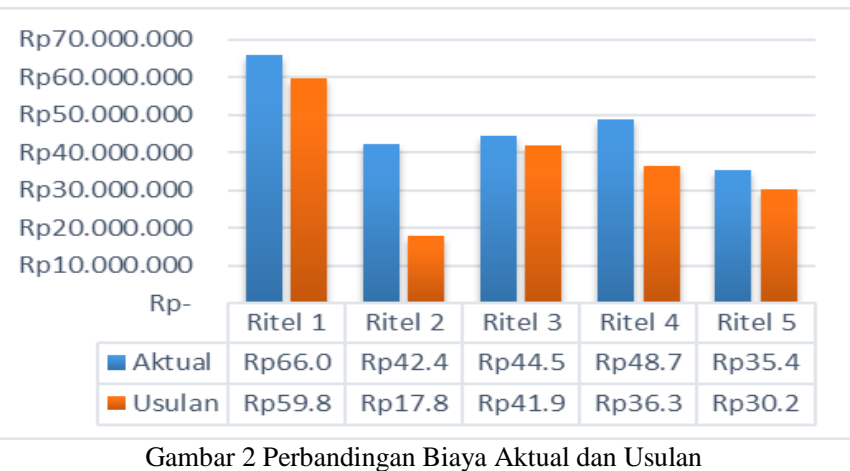

Total biaya pengiriman masing-masing ritel pada bulan Januari 2016 sampai Desember 2016 ini dijumlahkan sehingga didapatkan total biaya pengiriman usulan dengan menggunaan metode DRP sebesar Rp186.679.142,- lebih kecil dari biaya pengiriman aktual dengan menggunakan metode perusahaan sebesar Rp237.155.132,- dengan selisih Rp50.475.991,- atau penghematan sebesar $21 \%$ untuk 12 bulan

\section{KESIMPULAN}

Berdasarkan analisis, maka dapat disimpulkan sebagai berikut:

a. Dari hasil perancangan penjadwalan aktivitas distribusi dengan menggunakan metode Distribution Requirement Planning (DRP) dapat mengatasi permasalahan pemenuhan kebutuhan produk dimana meminimasi penumpukan dan kekosongan persediaan produk pada ritel.

Pada perancangan penjadwalan aktivitas distribusi usulan didapatkan rata-rata pemenuhan masing-masing produk pada tiap ritel bulan Januari 2016 sampai Desember 2016 mendekati kebutuhan ritel. Hal ini dapat dilihat pada Tabel 12

Tabel 12 Distribution Requirement Planning

\begin{tabular}{|c|c|c|}
\hline Ritel & Pemenuhan Usulan & $\%$ Pemenuhan Usulan \\
\hline Ritel 2 & 29743 & $100 \%$ \\
\hline Ritel 3 & 33644 & $100 \%$ \\
\hline Ritel 4 & 29527 & $100 \%$ \\
\hline Ritel 5 & 25202 & $100 \%$ \\
\hline
\end{tabular}

b. Total biaya pengiriman masing-masing ritel pada bulan Januari 2016 sampai Desember 2016 ini dijumlahkan sehingga didapatkan total biaya pengiriman usulan dengan menggunaan metode DRP sebesar Rp 186.679.14,- lebih kecil dari biaya pengiriman aktual dengan menggunakan 
metode perusahaan sebesar Rp 237.155.132,- dengan selisih Rp50.475.991,- atau penghematan sebesar $21 \%$ untuk 12 bulan.

\section{DAFTAR PUSTAKA}

[1] Pujawan, P. I., \& Mahendrawathi. Supply Chain Management Edisi Kedua. Surabaya: Guna Widya. 2012

[2] Indrajit, Eko \& Djokopranoto. Perkembangan Integrasi Perencanaan, Dari Materials Requirement Planning (Mrp) Sampai Ke Enterprise Resource Planning (ERP). 2007.

[3] Nurahma, D A., Ridwan, A Y., Santosa, B. Usulan Perencanaan Kebijakan Persediaan Vaksin Menggunakan Metode Continuous Review (s,S) untuk Mengurangi Overstock Di Dinas Kesehatan Kota XYZ, Jurnal Rekayasa Sistem \& Industri (JRSI) 3, 2016, pp. 47-51
[4] Titus Kristanto, Rachman Arief. Rancang Bangun Sistem Penjadwalan Aktivitas Distribusi Dengan Metode DRP (Distribution Requirement Planning). Prosiding Seminar Nasional 2013 Menuju Masyarakat Madani san Lestari pp. 709-720. 2013.

[5] Deviani, S., Ridwan, A Y., Santosa, B. Usulan Perencanaan Dan Penjadwalam Aktivitas Distribusi Air Minum Dalam Kemasan Gallon Untuk Meningkatkan Kemampuan Pemenuhan Permintaan Di Pabrik MKS Menggunakan Metode Distribution Requirement Planning (DRP). E-Proceeding of Engineering Vol.2 No.3 Desember 2016 pp.7550

[6] Ginting, R. I. (2007). Sistem Produksi. Yogyakarta: Graha Ilmu.

[7] Adib Fahrozi Abdillah. Perencanaan Dan Penjadwalan Aktivitas Distribusi Hasil Perikanan Dengan Menggunakan Distribution Requirement Planning (DRP). Jurnal Distribution Requirement Planning (DRP).

2009. 